International Background Paper

Wealth Tax Commission

\title{
Wealth taxes in France
}

Author

Jean-Marc Tirard OF ECONOMICS AND POLITICAL SCIENCE —

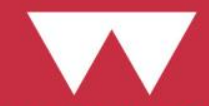
WARWICK WICK 


\section{WEALTH TAXES IN FRANCE}

Jean-Marc Tirard, Tirard, Naudin, France

Wealth Tax Commission Background Paper no. 135

Published by the Wealth Tax Commission

www.ukwealth.tax 


\section{Acknowledgements}

The Wealth Tax Commission acknowledges funding from the Economic and Social Research Council (ESRC) through the CAGE at Warwick (ES/L011719/1) and a COVID-19 Rapid Response Grant (ES/V012657/1), and a grant from Atlantic Fellows for Social and Economic Equity's COVID-19 Rapid Response Fund. 


\section{"L'ISF est un impôt imbécile" \\ - François Fillon, former French Prime Minister}

"The French have the passion of equality"

- Alexis de Tocqueville

\section{Brief history of wealth taxes in France}

History shows that in France wealth tax is more than a tax. Seen by a majority of the French population which is not subject to it as a tax on the "rich', it is a symbol of equality and the beacon of an ideology.

Over the last 40 years three different wealth taxes have applied in France: l'impôt sur les grandes fortunes (tax on great fortunes), l'impôt de solidarité sur la fortune (solidarity tax on wealth) and finally l'impôt sur la fortune immobilière (tax on real estate).

We currently refer to the impôt sur les grandes fortunes as the IGF, to the impôt de solidarité sur la fortune as the ISF, and at the impôt sur la fortune immobilière as the IFI.

The following developments focus on the ISF and the IFI, as the IGF only applied for four years and was very similar to the ISF.

By the expression 'wealth taxes', we refer to both the ISF and the IFI.

\subsection{Introduction of wealth taxes}

Even though the French wealth tax was only introduced in the French tax code at the beginning of the eighties, the idea of such a tax has been the subject of recurrent proposals since the Second World War. Furthermore, a temporary and exceptional tax 'of national solidarity"' on wealth was set up in 1945 by the French post-WWII government.

The wealth tax we knew for decades in the French tax system was introduced for the first time in 1982 by a socialist President, the late François Mitterrand, under the name 'impot sur les grandes fortunes' (tax on great fortunes). Every French household with a net worth exceeding 3 million French francs $(457,347 \text { euros })^{1}$ was concerned by this tax ${ }^{2}$. At that time, three main justifications were put forward in support of this new tax. It was supposed to affect assets that provided their holders with an additional contributory capacity, it was intended to respond to the criticism of insufficient taxation of capital in France, and, most importantly, it was designated as a redistribution tool aimed at reducing inequalities ${ }^{3}$.

\footnotetext{
${ }^{1}$ Finance Bill for 1982, n 450, explanatory statement under article 2, Dr. fisc., Oct. 1981, n 44, 100044.

${ }^{2}$ Two important reports, the $8^{\text {th }}$ report of the Conseil des impôts (a French institution responsible for assessing all compulsatory levies and making recommendations on all matters related to such levies, renamed the Conseil des prélèvements obligatoires in 2005) published in September 1986 and the report of the Acairdi Commission (commissioned by the minister of the Economy and Finance to assess the French rules on assets taxation) released in April 1988, were both highly critical toward the wealth tax set up in 1982.

${ }^{3}$ Loi n 86-824, 11 July, 1986, Loi de finances rectificatives pour 1986 [Amending Finance Act for 1986], art 24.
} 
The new wealth tax faced a lot of criticism ${ }^{4}$, and was finally dropped in 1986 with the arrival of the right-wing political majority to power ${ }^{5}$. However, as soon as the left-wing majority returned to power (1988), the wealth tax was reinstated on the same basis as the previous one with a slightly different name: 'l'impôt de solidarité sur la fortune', literally, the solidarity tax on wealth ${ }^{6}$. The minimum tax threshold was increased from 3 million francs (457,347 euros) to 4 million francs $\left(609,796\right.$ euros) and the marginal tax rate was decreased from $1.5 \%$ to $1.1 \%{ }^{7}$. This time the only justification officially put forward by the government for setting up this tax was the need to fund the 'revenu minimum d'insertion ${ }^{8}$ ' (the minimum insertion income), a social benefit designed to guarantee everyone a minimum level of resources ${ }^{9}$. This is definitely one of the reasons why the French wealth tax is perceived as a redistribution tool and an additional contribution by the wealthiest in favour of the most underprivileged. The very name given to this tax speaks for itself.

The French wealth tax has been heavily criticised by the current French president Emmanuel Macron. Although the tax was not abolished altogether it underwent a significant modification two years ago: the Finance Act $2018^{10}$ replaced the solidarity tax on wealth, known as the ISF, with a tax due solely on real estate, called the IFI. The mechanism of this new tax is almost entirely identical to the one it replaces, but its tax basis is significantly narrower since it is limited to real estate properties. The scope has thus been significantly reduced but the tax rates, general design and the minimum tax threshold have remained the same. It is interesting to note that the government tried to separate this new wealth tax from the political purposes of redistribution and solidarity. Indeed, the only ground exposed to parliament in the draft bill to support this reform was a financial one: 'This tax is instituted for budgetary purposes, so as to create a specific tax on the real estate properties of taxpayers with the most valuable real estate properties ${ }^{\prime 11}$. According to Emmanuel Macron, the replacement of the ISF by a tax limited to real estate is supposed to encourage the wealthier taxpayers to invest in productive corporations

\footnotetext{
${ }^{4}$ Loi no 89-1159, 23 Dec., 1988, Loi de finances pour 1989 [Finance Act for 1989], art. 26.

${ }^{5}$ This marginal rate concerned households whose assets were valued at more than 10 million francs, i.e. 1.53 million euros.

${ }^{6}$ Which became the "revenu de solidarité active" [Solidarity Income] in 2011.

${ }^{7}$ Finance Bill for $1989, n^{\circ} 160$, explanatory statement under article 18, in accordance with the promise made by late President François Mitterrand in his Lettre à tous les Français [Letter to all French], published 7 April, 1988.

${ }^{8}$ Loi n 2017-1837, 30 Dec. 2017, Loi de finances pour 2018(Finance Act 2018).

${ }^{9}$ Finance Bill 2018, $\mathrm{n}^{\circ} 235$ explanatory statement under article 12.

${ }^{10}$ According to a major study, if the reform of capital taxation that has occurred in France in 2018 should encourage investment in corporations, especially in equity, the most recent data available regarding French households' financial investment are not relevant to identify the impact of the reform. France Stratégie, $1^{e r}$ rapport du Comité d'évaluation des réformes de la fiscalité du capital [Committee for the evaluation of capital taxation reforms], Oct. 2019, p. 172-174. Available at: https://www.strategie.gouv.fr/publications/comite-devaluation-reformes-de-fiscalite-capital-premierrapport.

${ }^{11}$ According to the most recent report, the wealth tax reform has reduced the number of households subject to the wealth tax from 358,198 to 132,722 , i.e. about two thirds of the taxpayers. V. Eble, A. de Montgolfier, Rapport d'information $n^{\circ} 42$ (Sénat) fait au nom de la commission des finances sur l'évaluation de la transformation de l'impôt sur la fortune (ISF) en impôt sur la fortune immobilière (IFI) et de la création du prélèvement forfaitaire unique (PFU), Tome 1 (Information report $\mathrm{n}^{\circ} 42$ made on behalf of the Senate's Finance Commission on the evaluation of the replacement of the wealth tax estate assets by the wealth tax on real estate properties and the creation of the flat tax), Oct. 2019, p.87, available at: https://www.senat.fr/notice-rapport/2019/r19-042-1-notice.html.
} 
rather than in real estate. Although it is difficult to know if this purpose will be achieved ${ }^{12}$, it is clear that this reform has significantly reduced the number of households liable to wealth $\operatorname{tax}{ }^{13}$.The new tax has been criticised by those who own valuable real estate properties who perceive the tax as discriminating unfairly against those whose wealth is tied up in real estate rather than in financial assets. Equally, those who do not pay it consider the repeal of the ISF to be a gift to the rich. It is for this reason together with the replacement of progressive income tax by a flat tax of $30 \%$ on capital income that President Macron has been nicknamed the 'president of the rich'.

\subsection{Revenue raised by wealth tax}

\section{TABLE 1: REVENUE, €M, 2016-2019}

\begin{tabular}{|l|l|l|l|l|}
\hline & 2016 & 2017 & 2018 & 2019 \\
\hline ISF & 4,050 & 4,230 & & \\
\hline IFI & & & 1,290 & 2,100 \\
\hline
\end{tabular}

Sources: All the figures used can be found in the annual reports of the French Tax Administration (in French and in English), available at: https://www.economie.gouv.fr/dgfip/rapports-dactivite-dgfip.

In 2017, which was the last year of ISF before its replacement by the IFI, it was paid by 385,000 households and generated a revenue of 4.23 billion euros.

\subsection{Popularity and political debate}

The recent reforms of the French wealth tax and their political motivations are described above (see §1.2.).

French wealth taxes have been subject to much discussion: their economic efficiency is very questionable and has indeed been proven low whereas their cost to the French economy is significant.

One of the objectives of the wealth taxes was to take greater account of the contributory capacities of the wealthiest taxpayers. However, this objective seems to be no longer achieved and the taxpayers who are the most affected by the wealth tax are not necessarily the wealthiest as the tax is so limited in its tax base - i.e. to real estate.

A parliamentary report released in October $2019^{14}$ shows that numerous households are liable to the wealth tax without necessarily having high income. In 2017 for instance, $10 \%$ of the households liable to wealth tax had an annual tax revenue of less than 32,000 euros, with an average amount of wealth tax paid of 7,000 euros, and $20 \%$ of them had a tax revenue of less

\footnotetext{
${ }^{12}$ V. Eble, A. de Montgolfier, Rapport d'information n 42 (Sénat) fait au nom de la commission des finances sur l'évaluation de la transformation de l'impôt sur la fortune (ISF) en impôt sur la fortune immobilière (IFI) et de la création du prélèvement forfaitaire unique (PFU), Tome 1 (Information report $\mathrm{n}^{\circ} 42$ made on behalf of the Senate's Finance Commission on the evaluation of the replacement of the wealth tax estate assets by the wealth tax on real estate properties and the creation of the flat tax), Oct. 2019, p.87, available at: https://www.senat.fr/notice-rapport/2019/r19-042-1-notice.html.

${ }^{13} \mathrm{~V}$. Eble, A. de Montgolfier, Rapport d'information $n^{\circ} 42[. .$.$] prev. footnote n^{\circ} 14 .$, p. 35.

${ }^{14}$ According to the report just mentioned, the real estate property prices have risen by $75 \%$ in France from 2000 to 2018. Ibid. p. 34.
} 
than 48,000 euros ${ }^{15}$. This situation can partly be explained by strong inflation, especially of property prices that European countries and France have known for the past three decades ${ }^{16}$, which has not led to any modification of the wealth tax scale since 2013. The report emphasised the fact that some households became liable to the wealth tax solely because of the value of their real estate properties, without being particularly wealthy ${ }^{17}$. The tax was said to be a tax imposed on those who are capital rich but income poor. Moreover, the capping mechanism (see page 16) turned out to be almost totally inefficient for these households, as it mainly benefits the wealthiest taxpayers ${ }^{18}$ and excludes foreign taxpayers. Besides being very expensive for French public finances ${ }^{19}$, this measure does not fulfil the very purpose it was set up for.

It is perceived as unfair that wealth tax, as a tax on capital, is not due on income but on capital: there is therefore no certainty that the taxpayers will have enough cash to pay the amount of tax due, which has forced some of them to dispose of their assets or to emigrate. Although the tax was supposed to provide a better understanding of the contributory capacities of its taxpayers, it became apparent that such a contributory capacity was somewhat theoretical. Inquiring on this specific point, the French Constitutional Council however has ruled that 'the apprehension of the contributory capacity does not imply that only income-productive assets should be included in the wealth tax's basis' ${ }^{20}$. The only flexibility admitted in this respect concerns trusts: if the settlor manages to demonstrate that the assets he placed into a trust do not provide him with any contributory capacity (because he is excluded as a beneficiary and has no control), he may avoid the general rule stating that assets held in trusts are part of the settlor's real estate assets ${ }^{21}$. This proof is however very difficult to obtain since it is often possible for the settlor to request a distribution from the trustee for the legitimate reason of paying taxes.

Moreover, some assessment reports ${ }^{22}$ have shown that taxpayers most affected by wealth taxes were not necessarily the wealthiest, especially now that the French wealth tax is limited to real estate properties. Indeed, economic studies ${ }^{23}$ have demonstrated that the wealthier the household is, the less significant in value of the real estate compared to their total estate. As a result, if the rate of wealth tax is generally progressive, the average tax rate decreases once the

\footnotetext{
15 Ibid, p. 35.

$16 \mathrm{Ibid}$., p. 36-37. According to the report, in 2017 taxpayers in the first bracket of the scale represented only $13 \%$ of the beneficiaries of the capping mechanism and $0.5 \%$ of its cost.

${ }^{17}$ The report measures the cost of the capping at 1.326 million euros in 2017 and at 92 million euros in 2018, Ibid. p. 94.

${ }^{18}$ Cons. constit., 29 Sept.2010, n 2010-44 QPC, Epoux Mathieu; commented by O. FOUQUET, "L'assiette de l'ISF est-elle constitutionnelle?", Revue de droit fiscal, Oct. 2019, n 43, act. 398.

${ }^{19}$ This rule results from a decision of the French Constitutional Council, Cons. constit., 15 Dec. 2017, $\mathrm{n}^{\circ}$ 2017-679 QPC.

${ }^{20}$ Notably, C. Dherbecourt, C. Freppel, rapport particulier sur les prélèvements obligatoires des ménages $n^{\circ} 3$ (Conseil des prélèvements obligatoires), Les prélèvements obligatoires sur le capital permettent-ils d'appréhender la capacité contributive des ménages ?, (specific report of the Conseil des prélèvements obligatoires about capital taxation: Are taxes on wealth appropriate to understand the households' contributory capacity?), May 2017, p. 53-54, available at : https://www.ccomptes.fr/fr/publications/lesprelevements-obligatoires-sur-le-capital-des-menages.

${ }^{21}$ V. Eble, A. de Montgolfier, Rapport d'information $n^{\circ} 42$ (Sénat) [...] prev. footnote n¹4, p. 86.

${ }^{22}$ France Stratégie, Comité d'évaluation des réformes de la fiscalité du capital[...] prev. footnote $\mathrm{n}^{\circ} 12, \mathrm{p}$. 192.

${ }^{23} \mathrm{Ibid}$., p. 87 and following.
} 
threshold of 14.3 million euros of assets is exceeded ${ }^{24}$. Furthermore the 2018 reform limiting the tax base to real estate properties has led to a significant number of wealthier taxpayers being exempt from the wealth tax (or paying much less) ${ }^{25}$.

Another source of perceived unfairness is the lack of consideration for the overall family situation. In calculating income tax, households can benefit from a family quotient whose purpose is to adjust the amount of tax in consideration of the family situation ${ }^{26}$. This measure was however never extended to wealth taxes. As a result, married couples and families (including cohabitees - see below) are de facto more affected by wealth taxes than a single person: the tax basis will be constituted by their total assets and the marginal tax rate will therefore be higher than if the taxpayers were taxed on an individual basis. They receive no additional exempt threshold for being married. This situation is seen as unfair, particularly given that in the context of inheritance tax, another form of capital taxation, each taxpayer is taxed on his own assets and the household is not taxed as a single unit. This may be considered as discriminatory.

All these elements show that the French wealth tax even now continues to present significant issues that allow us to question its fairness. Its inability to tax efficiently the wealthiest households also puts in question its effectiveness toward achieving redistribution.

Despite their numerous technical issues and their low economic efficiency, French wealth taxes, because they are mainly perceived as a redistribution tool, are very popular. Hence, trying to remove or to lighten them presents a great political risk. The removal of the wealth tax by the late Jacques Chirac has been seen by many commentators as the measure that caused him to lose at the presidential election. The replacement of the ISF by the IFI by Emmanuel Macron has provoked great anger among a significant part of the French population and the reinstatement of the ISF is one of the main requests of the 'gilets jaunes'.

The French experience of wealth taxes highlights a paradox: while the wealth tax is, to a certain extent, inefficient and costly for the economy, it seems almost impossible to remove because such taxes are regarded by a great part of the French population as symbols of tax fairness.

\subsection{Regional differences}

The IFI, like earlier wealth taxes, is levied on a national level and applies uniformly to all taxpayers that are within its scope.

\footnotetext{
${ }^{24}$ The basis subject to the tax on incomes is divided by the numbers of family quotient shares - which depends on different factors (number of children, possible disabilities...) - that benefits the household, before the application of the tax rate. The result thus obtained after this calculation is multiplied by the number of family quotient shares.

${ }^{25}$ French Tax Code (CGI), anc. art. 885 I paragraph 1 and 2.

${ }^{26}$ French Tax Code (CGI), anc. art. 885 I paragraph 3 and 4.
} 


\section{What assets are taxed? Exemptions and reliefs}

\section{ISF}

Unless they were used for professional purposes (see below), all assets owned by individuals fell within the scope of the ISF. Some specific assets, however, could benefit from a full or partial exemption. This was notably the case for antiques, art or collectors' items ${ }^{27}$, intellectual property rights ${ }^{28}$, annuities, pensions and allowances ${ }^{29}$ and wood, forests and long-term leased rural property which were exempt as to $75 \%$ of value subject to certain conditions. Certain categories of shares were also not subject to ISF, such as shares belonging to employees or executive officers if they exercised their main activity in this corporation (up to three quarters of the shares' value) ${ }^{30}$.

The most notable exemption, and the one that caused most issues, concerned business assets ${ }^{31}$. Two main categories of assets were excluded from the scope of the wealth tax: first, assets needed for the taxpayer's main professional activity; secondly, assets belonging to the taxpayer and assigned to the activity of a corporation in which the taxpayer was an executive director or in which he exercised his main professional activity. This exemption effectively meant entrepreneurs were less adversely affected by the tax.

Another exemption benefited French financial investments of non-residents. This exemption did not apply to shares in a legal entity whose assets predominantly consisted of real estate situated in France nor to shares representing more than 10\% of a company's capital.

\section{IFI}

The IFI only concerns real estate. All real estate properties and real property rights are included in the tax base ${ }^{32}$, although note the discount for the main residence below. In the case of indirect holding (through a French or foreign corporation), shares are also included in the tax base in proportion to the value of properties held by the corporation, unless these properties are allocated to an operational activity ${ }^{33}$ of the corporation that holds them.

A class exemption has been set up in favour of business assets ${ }^{34}$. Real estate properties are exempt from the IFI as long as they are assigned to the tax payer's main activity or to the operational activity of the corporation in which he is an executive director / exercises his main activity. In cases of indirect holdings, the exemption may apply to the value of shares in proportion to the value of properties held by the corporation. This exemption is however one of

\footnotetext{
${ }^{27}$ French Tax Code (CGI), art. $885 \mathrm{~J}$.

${ }^{28}$ French Tax Code (CGI), anc. art. 885 I quarter.

${ }^{29}$ French Tax Code (CGI), anc. art. $885 \mathrm{~N}$ to $885 \mathrm{R}$.

${ }^{30}$ However, are not concerned by the wealth tax minority shareholdings, i.e. shareholdings representing less than $10 \%$ of the capital.

${ }^{31}$ For the purpose of this measure, an activity is considered operational if it is an industrial, commercial or artisanal activity. Real estate property management is thus not considered an operational activity.

${ }^{32}$ French Tax Code (CGI), art. 975.

${ }^{33}$ French Tax Code (CGI), anc art. 885 G; art. 970. Charitable trusts and retirement trusts are however not concerned by the wealth tax.

${ }^{34}$ Under the regime of separation of property each spouse retains the administration of all his or her present or future property and has the free enjoyment and disposition of both capital and income (French Civil Code, art 1536).
} 
strict interpretation and cannot, for instance, benefit properties assigned to the subsidiary or the sub-subsidiary of the corporation in which the taxpayer is an executive director / exercises his main activity.

Example 1: if a company having a business activity also owns a real estate property which is used by the business, the IFI exemption applies.

Example 2: the exemption also applies if the real estate property used by the business is owned by a subsidiary of the company.

Example 3: on the other hand, the exemption does not apply if a holding company performs the business activity and owns the real estate property through two different subsidiaries, even if the property is used by the business.

In our opinion, the difference of treatment depending on the structure of ownership is not rational.

A specific rule regarding assets held in a trust in respect of the ISF was added in the French Tax Code in 2011 and was also implemented in the rules governing the IFI. According to this rule, assets held in a trust, regardless of its characteristics, are considered as part of the settlor's estate at the value as established on 1 January ${ }^{35}$. It is crucial to determine the settlor's tax residency on 1 January in order to determine which assets are caught by wealth taxes. If the settlor is a French tax resident, all assets (since IFI is now limited to real estate) transferred into the trust are subject to wealth taxes, regardless of their location; otherwise, wealth taxes only apply to assets (since IFI is limited to real estate) located in France.

${ }^{35}$ French Tax Code (CGI), anc art. 885 G; art. 970. Charitable trusts and retirement trusts are however not concerned by the wealth tax. 


\section{Who pays - design of the tax base for individuals and trusts}

\subsection{Individuals and families}

The ISF concerned households whose net worth exceeded the threshold of 1.3 million euros on 1 January of each year. All assets belonging to members of the tax household were included in the scope of the ISF as long as they did not fall under a specific exemption.

The IFI concerns households whose real estate properties are valued at more than 1.3 million euros on 1 January of each year. As was already the case with the ISF, all real estate properties belonging to members of the tax household are taken into account.

Therefore, married couples, whatever their marriage regime, and people living as common law husband and wife are (with certain exceptions) subject to joint assessment for ISFand IFI," In order for couples living together to be considered as de facto husband and wife " concubinage notoire"' case law requires the simultaneous satisfaction of three criteria: stability, continuity, and that they live together publicly as husband and wife. Moreover, property belonging to minors who are under the legal custody of a 'spouse' is added to the property belonging to the couple.

The only exception to this common taxation concerns couples that are married under the regime of the separation of property ('séparation de biens') ${ }^{36}$ and no longer live under the same roof, and married couples in the process of divorce or judicial separation.

Wealth tax (like income tax) is due from the household as a whole. A minor child is not a separate taxpayer. Hence all income received by the parents and minor children composing each household are subject to income tax and all assets owned by the parents and minor children of the same household are subject to the same wealth tax. In order to prevent wealth tax from being confiscatory, wealth tax and income tax due from the same household cannot exceed $75 \%$ of its previous year's income (see page 16).

\subsection{Trusts}

A specific rule regarding assets held in a trust in respect of the ISF was added in the French Tax Code in 2011, and was also implemented in the rules governing the IFI. According to this rule, assets held in a trust, regardless of its characteristics and the power retained by the settlor, are considered as part of the settlor's estate assets for their current value as established on 1 January ${ }^{37}$.

\footnotetext{
${ }^{36}$ For a more detailed presentation of the trustee's reporting obligation, see our precedent paper 'Everything You Always Wanted to Know About Trusts with a French Connection (But Were Afraid to Ask)', ACTEC Philadelphia; Oct. 18, 2019.

${ }^{37} \mathrm{~A}$ trust is regarded as having a connecting factor with France if either: the grantor/settlor is a French resident for tax purposes; at least one of the beneficiaries is a French resident for tax purposes; the trust holds French located assets; the trustee is a French tax resident or, being resident or established outside the European Union, either acquires real property located in France or enters into a business relationship in France (as defined by the French Monetary and Commercial Code).
} 
It is crucial to determine the settlor's tax residency on 1 January in order to determine which trust assets are affected by wealth taxes. If the settlor is a French tax resident; all trust assets are subject to wealth taxes, regardless of their location; otherwise, wealth taxes only concern assets located in France.

In any event note the annual reporting obligations of the trustees ${ }^{38}$. If the trust has any French connection $^{39}$, the trustee should declare the current value of the worldwide assets held through the trust. If neither the settlor nor the beneficiaries are French taxpayers, the trustee should report the current value of the assets located in France. Assets held through a trust must appear on the settlor's wealth tax return, otherwise, the trustee will face a 1.5\% tax on the current value of all the trust assets subject to wealth tax (now limited to real estate as set out above) and without any 1.3 million euro exemption threshold.

${ }^{38}$ French Tax Code (CGI), art. 964.

${ }^{39}$ French Tax Code (CGI), art. 964. 


\section{Territoriality}

\subsection{Non-residents}

The territoriality rule is the same for the ISF as for the IFI: French tax residents are liable to wealth taxes on their worldwide taxable assets, regardless of their location, whereas nonFrench tax residents' liability is limited to their taxable assets located in the French territory which they directly or indirectly own ${ }^{40}$, unless otherwise stated by the relevant tax treaty.

When intermediate companies are used, the fraction of the market value of the company's shares owned by the tax payer representing the market value of the underlying real estate properties, compared with the market value of its other assets, is taken into consideration for IFI purposes. As a result, in a case where French real estate assets are held through a foreign company held by a non-resident, the shares are also included in the tax base in proportion to the value of properties held by the company. Where non-French real estate is held through a French or foreign company held by a French resident, again the value of the shares is included in the tax base in proportion to the value of those foreign properties.

\subsection{New residents}

A favourable incentive has been provided for the benefit of persons transferring their tax residence to France: they will only be subject to wealth tax on their real estate properties located outside France after a five-year period following their transfer of tax residence ${ }^{41}$.

Tax residence is defined the same way in France for all tax purposes. Consequently, an individual is deemed to be resident in France for wealth tax purposes if the individual: (1) has his or her home or maintains a primary place of residence in France; (2) practices a profession in France, unless he or she can demonstrate that such activities in France are merely incidental; or (3) if his or her 'centre of economic interest' is in France.

As from January 12020 , executive officers of companies whose registered office is located in France are deemed to practice their main profession in France, if the concerned company has a turnover in excess of 250 million euros.

\subsection{Exit tax}

An exit tax was reinstated in the French tax legislation as of 3 March 2011, although it does not specifically relate to wealth tax but is due in respect of unrealised capital gains.

This tax applies to any individual who transfers his tax residence abroad after six years of continuous residence in France and who holds, whether directly, indirectly or jointly with the members of his household, either (i) a participation of at least $50 \%$ in a company, or (ii) a participation (in such a company) whose value exceeds 800,000 euros at the date of the transfer.

\footnotetext{
${ }^{40}$ The notion of current value has been defined as "the price that could be obtained by the interplay of supply and demand in an actual market”. Cass. com., Oct .23, 1984, $n^{\circ} 82-17054$. This definition has also been adopted by the Tax Administration, BOI-ENR-DMTOI-10-10-20-40 n¹, 12-09-2012.

${ }^{41}$ French Tax Code (CGI), art. $885 \mathrm{~S}, 2^{\text {nd }}$ paragraph.
} 
When these conditions are met, the transfer of residence will trigger flat tax at the rate of $30 \%$, or, upon election from the taxpayer, progressive income tax and social contributions, on any rolled over gains and unrealised gains calculated at the date of the transfer. However, the taxpayer benefits from an automatic deferral if he becomes resident in an EU State or an EEA State which has entered into a tax agreement with France in order to facilitate the exchange of information and the collection of taxes. Otherwise, income tax and social contributions are immediately payable unless the taxpayer requests a deferral and provides an appropriate guarantee for the payment of such taxes (no guarantee is required if the transfer of residence is for professional reasons). In both cases, the deferral will end and tax will become payable when the shares are sold, cancelled, repurchased, reimbursed, transferred by way of gift in certain circumstances or when the taxpayer receives earn out payments. The crystallised income tax on unrealised gains is exempt after 15, 8, 2 or 5 years depending on the date of the transfer and the value of the transferable assets, or if the taxpayer relocates earlier to France (provided he still holds the shares) or upon his earlier death.

If the exit tax is payable, it can either be reduced if the actual gain is eventually lower than the crystallized gain at the time of the transfer of residence, or it can simply be cancelled if the transfer has generated a loss. In order to avoid double taxation, the tax paid abroad in the country of residence upon the disposal of the shares can be credited against the French exit tax.

However, no wealth taxes are payable after the individual's departure from France except on French real estate. 


\section{Valuation issues}

Wealth taxes are based on the market value of the taxable assets on 1 January of each year. No independent professional valuation is required. The taxpayer is responsible for the reporting and valuation of his/her assets ${ }^{42}$ subject to possible adjustments (and related penalties) by the French Tax Authority (FTA) if taxable assets are not reported and/or their valuation is challenged.

Wealth tax is therefore a self-assessed tax subject to review by the FTA.

The valuation of property on 1 January of each year outside of any sales, is necessarily difficult and somewhat theoretical. Furthermore, taxpayers are not allowed to deduct taxes on capital gains, due when assets are sold. If their assets are undervalued, they run the risk of an adjustment by the FTA. If they are overvalued, they will pay more taxes than they should. The risk of undervaluation is real and not uncommon. It requires the FTA to commit additional resources in order to limit the risk, which makes the cost of the wealth tax collection higher than for income tax. A discount may be allowed when circumstances justify it (e.g. in respect of minority shares in private companies).

Debts owed by the taxpayer are valued to their nominal value plus any interest already due or accrued. See also further details below

When intermediate companies are used to hold real estate properties, the fraction of the market value of the company's shares owned by the tax payer representing the market value of the underlying real estate properties, compared with the market value of its other assets, is taken into consideration for IFI purposes.

An allowance of $30 \%$ applies to the value of the principal residence ${ }^{43}$. Each household has only one principal residence which is the place where the family members live on a habitual basis. As a consequence, the $30 \%$ does not apply to non-resident taxpayers. The $30 \%$ allowance only applies if the principal residence is directly owned by one of the household's members. If a company is interposed, the allowance is not granted.

Various tax reductions could reduce the amount of ISF due. The first one was set up in $2007^{44}$ with the aim of encouraging investments in small and medium enterprises (SMEs) and consisted of a tax reduction equivalent to $50 \%$ of capital increases in favor of $\mathrm{SMEs}^{45}$, within a limit of 50,000 euros. To benefit from this reduction, the taxpayer was required to hold the securities for a five-year period ${ }^{46}$.

The second exemption concerned taxpayers who made gifts to charities, exhaustively listed by the French Tax Code, located in France or in the EU. These organizations included: research or

\footnotetext{
${ }^{42}$ Loi n 2007-1223, 21 August 2007, Loi en faveur du travail, de l'emploi et du pouvoir d'achat (Act in favour of labour, employment and purchasing power), known as "Loi TEPA".

${ }^{43}$ For the purpose of this measure, SMEs are defined in accordance with the European definition of a SME, i.e. enterprises which employ fewer than 250 persons and which have an annual turnover not exceeding 50 million euros ( 54.8 million dollars), and/or an annual balance sheet total not exceeding 43 million euros (47.1 million dollars).

${ }^{44}$ The shares so received had to be held until the 31 December of the fifth year following the subscription.

${ }^{45}$ French Tax Code (CGI), art. 978.

${ }^{46}$ French Tax Code (CGI), art. 979.
} 
higher education establishments, charitable foundations, academic foundations or some employer associations. $75 \%$ of the amount of eligible gift was deductible from the wealth tax due, within an annual limit of 50,000 euros ${ }^{47}$. This specific tax cut has been implemented in the rules governing the IFI.

Moreover, in order to prevent wealth tax from being confiscatory, the French Legislator set up a tax cap: the total amount of the wealth tax due, added to the amount of the other taxes on the income, could not exceed $75 \%$ of the previous year's income, taking into account the worldwide income of all the household's members ${ }^{48}$. This capping only assists French tax residents. Foreign taxpayers cannot benefit from it. The author considers this measure is discriminatory.

${ }^{47}$ French Tax Code (CGI), anc. art. 885 I paragraph 1 and 2.

${ }^{48}$ Loi n 2011-900, 29July 2011, Loide finances rectificative pour 2011[Amending Finance Act for 1982] 


\section{Liquidity concerns}

\subsection{Illiquid assets}

Wealth taxes are not due on income but on capital, whether or not the taxable assets produce income: there is therefore no certainty that the tax payer will have enough resources to pay the amount of tax due, and the French legislation originally did not provide for any specific measure to prevent this issue until a tax capping mechanism was adopted (see 5.3).

In certain cases, it might therefore arise that a taxpayer has no other choice than to dispose of his assets to pay the amount of tax due or to put himself outside of the wealth's tax scope, i.e. having a net worth of less than 1.3 million euros. He may alternatively decide to leave France and take up residence in another country, which is perhaps one key reason why French tax payers emigrate to more friendly tax jurisdictions

However, given the $30 \%$ discount on main residences and the $100 \%$ exemption for pension wealth which together make up the majority of most people's wealth, the liquidity issues at least under ISF mainly affected the very wealthy who were capital rich and income poor. Even then they were assisted by the tax cap discussed in 6.3 below which relieved some liquidity problems.

\subsection{Reliefs and exemptions}

There are no such reliefs either for the purposes of the ISF or now of IFI although collectors' items ${ }^{49}$ were excluded from the scope of ISF.

As explained above (see §6.1.), there was no specific exemption or provision in the case of farmers with high land value but low yield.

The only protection that existed was the general tax $\operatorname{cap}^{50}$ according to which the total amount of the wealth tax due, added to the amount of the other taxes on income, could not exceed $75 \%$ of the previous year's income, taking into account the worldwide income of all the household's members ${ }^{51}$. This capping only assisted French tax residents. Non-resident taxpayers did not benefit from the tax cap.

\subsection{Borrowing}

For the calculation of the ISF, a deduction was allowed for all debts incurred in covering the purchase price and any improvements related to a real estate asset within the scope of wealth tax, as long as such costs were supported with evidence by the taxpayer.

By contrast, the rules governing the deductibility of debts for the determination of the IFI tax base are very restrictive ${ }^{52}$. Deduction is limited to debts incurred in respect of financing the purchase of the property and associated costs which are listed exhaustively in the French Tax

\footnotetext{
${ }^{49}$ French Tax Code (CGI), art. 979.

${ }^{50}$ French Tax Code (CGI), art. 974.

${ }^{51}$ French Tax Code (CGI), art. $990 \mathrm{D}$ to G, created by the Finance Act for 1983 (at the same time as the wealth tax), Loi n 82-1126, Dec. 29, 1982, Loi de finances pour 1983[Finance Act for 1983].

${ }^{52}$ France Stratégie, Comité d'évaluation des réformes de la fiscalité du capital [...] prev. footnote $n^{\circ} 12$, p. 14.
} 
Code, to a maximum extent of $50 \%$ of the value exceeding 5 million euros to the event that the amount of debt exceeds $60 \%$ of the taxable property's value.

The deduction is given for outstanding capital and accrued but unpaid interest as it subsists at 1 January of each year.

Only arm's lengths loans granted to finance the purchase of French real estate by non-residents are deductible but the non-resident may therefore charge up the French property as much as possible with debt even if they can afford to purchase it outright with cash. The borrowing does not need to be done through a French bank so borrowings from a UK bank can be allowed but connected party loans, e.g. between a company and its shareholders, are not allowable. 


\section{Relationship with other taxes}

In addition to the taxation on capital gains and ordinary income on investments, French taxpayers face no less than three main taxes on capital: inheritance and gift tax, local taxes on real estate properties and wealth tax. In addition to these, a sui generis tax is due by trustees of French connected trusts when the settlors (or the beneficiaries 'deemed settlors') are liable to wealth tax but did not comply with their reporting and payment requirements in this respect. We must also mention the $3 \%$ tax on properties held by corporations, which was set up in order to prevent taxpayers avoiding wealth tax by interposing corporations between them and their real properties ${ }^{53}$. As a result, capital taxation is therefore particularly high in France, reaching $11 \%$ of the GDP which is $2.2 \%$ higher than the average for European countries ${ }^{54}$.

The removal of the ISF and the introduction of the IFI has led to a significant reduction in the scope of the French Wealth Tax, which is now very different from the scope of other taxes on capital. Anyhow, the ISF and the IFI are both specific taxes with their own characteristics and are not related to other taxes on capital.

The only similarity between inheritance and gift tax and French wealth taxes is the valuation method of taxable assets which has to be done according to the rules of property valuation for inheritance tax purposes.

The applicable rates and reliefs for inheritance and gift tax purposes are entirely different from those applying to wealth taxes. The inheritance and gift tax rates depend on the degree of relationship of the beneficiary to the donor or the deceased ${ }^{55}$. For instance, inter vivos gifts to a spouse are taxed at progressive rates that vary from $5 \%$ to $45 \%$, but transfers to greater than fourth degree or other beneficiaries are taxed at a $60 \%$ flat rate.

Wealth taxes are never taken into account in the calculation of other taxes on capital but various wealth tax reductions have been introduced over the years. The first one was set up in $2007^{56}$ with the aim of encouraging investments in small and medium enterprises (SMEs) and consisted of a tax reduction equivalent to $50 \%$ of capital increases in favour of $\mathrm{SMEs}^{57}$, within a limit of 49,364 dollars $^{58}$. To benefit from this reduction, the taxpayer was subject to holding the securities received in return for a five-year period ${ }^{59}$. It was removed with the withdrawal of the ISF.

The second exemption relates to the tax cap described in 5.3 above.

The third exemption concerns taxpayers who made gifts to charities, exhaustively listed by the French Tax Code, located in France or in the EU. These organisations included: research or

\footnotetext{
${ }^{53}$ French Tax Code (CGI), art. 777.

${ }^{54}$ Loi n 2007-1223, 21 August 2007, Loi en faveur du travail, de l'emploi et du pouvoir d'achat, [Act in favour of labour, employment and purchasing power], known as "Loi TEPA".

${ }^{55}$ For the purpose of this measure, SMEs are defined in accordance with the European definition of a SME, i.e. enterprises which employ fewer than 250 persons and which have an annual turnover not exceeding 50 million euros ( 54.8 million dollars), and/or an annual balance sheet total not exceeding 43 million euros (47.1 million dollars).

5645,000 euros.

${ }^{57}$ The shares so received had to be held until the 31 December of the fifth year following the subscription.

${ }^{58}$ French Tax Code (CGI), art. 978.

${ }^{59}$ French Tax Procedure Handbook, article L. 64.
} 
higher education establishments, charitable foundations, academic foundations or some employer associations. $75 \%$ of the amount of eligible gifts were deductible from the wealth tax due, within an annual limit of 50,000 euros $^{60}$ (54,850 dollars). This specific tax cut has been implemented in the rules governing the IFI.

${ }^{60}$ Conseil d'État, plén. fisc., 25 oct. 2017, n 396954, Verdannet, Dr. fisc., janv. 2018, n 2, comm. 64, concl. E. Crepey, note F. Deboissy; C. de la Mardière, «Abus de droit: affres et misères de la jurisprudence Verdannet », RDF, juill. 2019, $\mathrm{n}^{\circ} 29$, étude 330. 


\section{Planning and avoidance}

\section{ISF}

In addition to investing in non taxable assets (e.g. art and antiques), a common wealth tax planning technique consisted in spreading assets amongst descendants although this could entail gift tax.

Subject to certain conditions including a conservation agreement by the family members, the 'Dutreil scheme' allowed up to three quarters of the value of a family business to not be subject to wealth tax.

Another commonly used tax planning technique consisted in accumulating income within a holding company. Under certain very strict conditions very often challenged as not being met, the holding company could qualify for business exemption. In any case not distributing dividend to the holding's shareholders allowed the latter to maximise the benefit of the wealth tax capping.

Under the ISF, financing the purchase of a French property through a loan was a common practise to reduce the taxable value of the property even if the loan was granted by a nonFrench lender. An anti-avoidance measure was however applicable as of 1 January 2012 according to which the valuation of shares of a company that owns a French property cannot be reduced by any debts owed to its non-resident shareholders.

\section{$|F|$}

Deduction of debts for IFI purposes has been significantly limited (see above §6.4). The main limitations relating to the deduction of loans concern borrowings by the individual taxpayer. As a consequence, using at least one intermediate company which owns the real property and borrows to finance its acquisition can be very efficient.

It is also beneficial to own real estate properties through the company which runs the business using these properties. Using another company to hold the property which is then used by the business owned in another standalone company would not benefit from an IFI exemption.

Although there is no specific anti-abuse rule in respect of wealth tax two general anti-avoidance rules can be used by the FTA for wealth taxes purposes.

The first one is the abuse of right doctrine ${ }^{61}$, that allows the FTA to ignore an arrangement or a series of arrangements, if they have been put in place with the sole purpose of mitigating the tax burden which would normally have been borne. Recently, a significant case law development has led to an extension of the scope of the abuse of right: the FTA is now able to use it each time it faces 'artificial arrangements deprived of any economic substance'62. A tax adjustment on the ground of the abuse of right is serious, as it involves the automatic application of an $80 \%$ penalty that can, in certain cases, be lowered to $40 \%$.

${ }^{61}$ This rule will enter into force on January $1^{\text {st }}, 2021$ but will cover acts carried out as from January 1st, 2020.

${ }^{62}$ French Tax Procedure Handbook, article L. 64 A. 
As of 1 January $2021^{63}$, another general anti-abuse rule will give the FTA the possibility to ignore an arrangement or series or arrangements that, seeking the benefit of a literal application of texts or decisions against the objectives pursued by their authors, have been put in place in the main purpose of mitigating the tax burden which would normally have been borne ${ }^{64}$. The wording of this rule is similar to the abuse of right doctrine, but its use will be much wider as it only requires the administration to prove that the tax purpose was the main motivation for the questioned arrangement. The application of the $80 \%$ or $40 \%$ penalty will however be excluded in that case.

There are, to our knowledge, few tax adjustments made on the ground of the abuse of right doctrine.

However, the abuse of rights doctrine could apply if there is an artificial attempt to fragment wealth tax holdings by spreading shareholdings among many members of the family and thereby create minority values.

\footnotetext{
${ }^{63}$ The first bracket of the wealth tax scale concerns assets with a value between 800,001 euros and 1.3 million euros. However, we remind you that households with real estate properties valued at less than 1.3 million euros are not concerned by the wealth tax.

${ }^{64}$ The notion of current value has been defined as "the price that could be obtained by the interplay of supply and demand in an actual market". Cass. com., 23 Oct. 1984, $n^{\circ} 82-17054$. This definition has also been adopted by the Tax Administration, BOI-ENR-DMTOI-10-10-20-40 n¹, 12 Sept. 2012.
} 


\section{Rates and bands}

The progressive scale rate, which is not related in any manner to income tax rates, is the same for ISF as for the IFI. The marginal $1.5 \%$ rate concerns households whose assets are valued at more than 10 million euros.

\section{TABLE 2: RATE SCALE, ISF/IFI}

Fraction of the net value of taxable assets

\section{Under 800,000 euros}

From 800,001 to 1.3 million euros

From 1,300,001 t0 2.57 million euros

From 2,570,001 to 5 million euros

From $5,000,001$ to 10 million euros

Over 10 million euros
Tax rate (\%)

0

0.50

0.70

1

1.25

1.50

\subsection{Example scenarios}

When appropriate, each of the scenarios will be examined under the ISF and the IFI.

\section{(i) Individual owns two houses each worth net}

For this scenario, the wealth tax payable would be the same under the ISF and the IFI. Indeed, both taxes apply to real estate properties and the IFI tax scale is the same as the ISF tax scale.

In the case where one of the two houses were the primary residence of the taxpayer, a $20 \%$ base reduction would apply.

(a) 500,000 euros

Both ISF and IFI only concerns households with a net worth exceeding 1.3 million euros on 1 January. In that scenario, no wealth tax would be due.

(b) 1 million euros

Idem

(c) 2 million euros

The wealth tax basis would be 2 million euros, and the amount of ISF/IFI due would be $€ 7,400$.

\begin{tabular}{|l|l|l|l|l|}
\hline $\begin{array}{l}\text { Taxable worth net: } \\
\text { From }(€)\end{array}$ & To $(€)$ & Tax basis $(€)$ & Rate & ISF/IFI due $(€)$ \\
\hline 0 & 800,000 & 800,000 & $0.00 \%$ & 0 \\
\hline 800,000 & 1.3 million & 500,000 & $0.50 \%$ & 2,500 \\
\hline 1.3 million & 2.57 million & 700,000 & $0.70 \%$ & 4,900 \\
\hline 2.57 million & 5 million & 0 & $1.00 \%$ & 0 \\
\hline 5 million & 10 million & 0 & $1.25 \%$ & 0 \\
\hline 10 million & & 0 & $1.50 \%$ & 0 \\
\hline Total & & 2 million & & 7,400 \\
\hline
\end{tabular}


(d) $€ 10 m$

The wealth tax basis would be 10 million and the amount of ISF/IFI due would be 98,190 euros.

\begin{tabular}{|c|c|c|c|c|}
\hline \multicolumn{2}{|c|}{ Taxable worth net: } & Tax basis $(€)$ & Rate & ISF/IFI due (€) \\
\hline 0 & 800,000 & 800,000 & $0.00 \%$ & 0 \\
\hline 800,000 & 1.3 million & 500,000 & $0.50 \%$ & 2,500 \\
\hline 1.3 million & 2.57 million & 1.27 million & $0.70 \%$ & 8,890 \\
\hline 2.57 million & 5 million & 2.43 million & $1.00 \%$ & 24,300 \\
\hline 5 million & 10 million & 5 million & $1.25 \%$ & 62,500 \\
\hline 10 million & & 0 & $1.50 \%$ & 0 \\
\hline Total & & 10 milion & & 98,190 \\
\hline
\end{tabular}

(e) $€ 20 m$

The wealth tax basis would be 20 million euros and the amount of ISF/IFI due would be 248,190 euros.

\begin{tabular}{|l|l|l|l|l|}
\hline $\begin{array}{l}\text { Taxable worth net: } \\
\text { From }(€)\end{array}$ & To $(€)$ & Tax basis $(€)$ & Rate & ISF/IFI due $(€)$ \\
\hline 0 & 800,000 & 800,000 & $0.00 \%$ & 0 \\
\hline 800,000 & 1.3 million & 500,000 & $0.50 \%$ & 2,500 \\
\hline 1.3 million & 2.57 million & 1.27 million & $0.70 \%$ & 8,890 \\
\hline 2.57 milion & 5 million & 2.43 milion & $1.00 \%$ & 24,300 \\
\hline 5 million & 10 million & 5 million & $1.25 \%$ & 62,500 \\
\hline 10 million & & 10 million & $1.50 \%$ & 150,000 \\
\hline Total & & 20 million & & 248,190 \\
\hline
\end{tabular}

\section{(ii) As above but the individual is married and assets split between the two of them}

The amount of ISF / IFI due would be exactly the same as determined above, as the ISF and the IFI both concern the global net worth of all household's members.

\section{(iii) Individual owns private trading company shares}

IFI only concerns real estate properties. As a consequence, unless the company holds real estate properties, no IFI would be due in that scenario.

This scenario will therefore be examined under the ISF only.

If we consider the entire shares' value as taxable, the amount of ISF due would be exactly the same as the amount calculated in the previous scenario.

However, the exemption in favour of business assets could possibly applies, either:

- The company is a partnership in which the taxpayer exercises his main professional activity, or 
- The taxpayer is one of the company's executive officers and holds more than $25 \%$ of the shares.

(iv) As in (iii) above but company is an investment company

The scenario would be quite close to the previous one. However, in that case, the benefit of the business assets class exemption seems to be impossible, unless the taxpayer is one of the company's executive officers and holds more than $25 \%$ of the shares.

(v) As in (iv) above but the assets are quoted shares and securities owned by the individual directly

The fact that the shares are quoted does not make any difference for ISF purposes. 


\section{Assessment, collection and general administration}

\subsection{Administrative costs}

Total administrative costs are close to 103 million euros, of which

- 35.3 million euros relates to management (includes valuation, collection, and litigation)

- 67.6 million euros relates to control.

These costs include the payroll of all jobs directly and indirectly dedicated to collecting the wealth tax as well as the share of operating costs, such as property, IT etc. Administrative costs account for $2.07 \%$ of the wealth tax collected in 2016 (ratio between administrative costs and gross yield without adjusting for tax refunds)

In comparison, administrative costs amount to $1.8 \%$ of the tax take for income tax (/'Impôt sur le revenu) and $2.52 \%$ for housing tax (/a taxe d'habitation) in 2016. In total, administrative costs of tax collection are equivalent to $0.78 \%$ of total tax revenue in 2016. (Note that there were 351,152 wealth tax returns in 2016. Total revenue from the wealth tax equalled 5.051 million euros in 2016.)

\subsection{Collection and assessment}

As explained above (see $\S 5.1$ ), the taxpayer is responsible for the reporting and valuation of his/her assets and is exposed to possible adjustments (and related penalties) by the FTA if the valuation is challenged. The valuation and self-assessment must be carried out annually, as the IFI basis consists of the taxable assets' net worth as it is valued on 1 January of each year. However, in the case of IFI the taxpayer waits for the Revenue's assessment before paying- see below.

In addition to other reporting obligations, there is a specific and separate wealth tax return to file. Therefore, the taxpayers must annually declare the gross and the net taxable value of all the assets concerned by the wealth tax. In addition, trustees of trusts with some connection to France, as set out above, are required to disclose to the FTA the identity of the parties to the trust as well as the market value of the trust's assets.

Each taxable asset needs to be separately reported on the forms with the address, or constituency, and market value on 1 January of the given year. Deductible debts relating to each taxable asset should also be reported.

\subsection{Form filling}

The IFI return is easier to complete than the ISF return since only real estate properties should be reported for IFI purposes when all assets should have to be reported for IFI purposes. The form filling does not typically take long provided the client knows the market value of the taxable properties (an independent valuation is not legally required). Most of the taxpayers complete their own returns. The only time-consuming exercise is the valuation of the taxable properties which is done by the client. 


\subsection{Enquiry, payment, enforcement and time limits}

The FTA may challenge the market value of assets for 3, 6 or 10 years (see below). The taxpayer may also correct the reported value during the same period. Wealth tax returns are statute barred from enquiry after 3 years if enough information was provided in the return ( 6 years in other cases except in respect of foreign assets and assets held through trusts for which the statutory period is 10 years). For non-residents the time limits are the same.

The interest rate on unpaid wealth tax is $2.4 \%$ per year since 2017 (4.80\% before). Depending on the circumstances, penalties are due at either $40 \%$ or $80 \%$.

ISF tax was payable upon the filing of the return. IFI is payable when the assessment established by the FTA is received by the taxpayer so in this respect it is not self-assessment tax. As a general rule, payment of the tax cannot be deferred.

FTA may put a line on assets located in France. A court order is not necessary. As non-resident taxpayers are subject to wealth tax only on French assets it is not difficult for the FTA to enforce payment regardless of the country of residence of the taxpayers.

\subsection{Appeals mechanisms}

The appeals mechanisms are the same as those applicable to all other French direct taxes. The first one is an internal appeal. If no agreement is reached with the FTA, the taxpayer should file an appeal to the tax court. If the taxpayer is not happy with the tax court's decision, he can file an appeal to the Court of Appeal and then to the Supreme Court. The whole process may take ten years or more. 